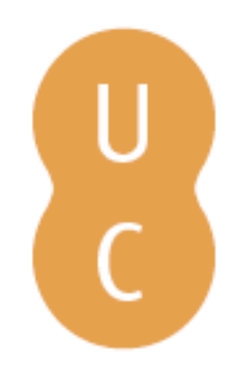

\title{
nommalina
}

\section{El mito de la Diosa-Tierra y el Paraíso Perdido en Menesteos, marinero de abril de María Teresa León}

Autor(es): $\quad$ Núñez Molina, María Lourdes

Publicado por: Imprensa da Universidade de Coimbra

URL

persistente: URI:http://hdl.handle.net/10316.2/44007

DOI: $\quad$ DOI:https://doi.org/10.14195/978-989-26-1550-9_5

Accessed : $\quad$ 26-Apr-2023 05:30:45

A navegação consulta e descarregamento dos títulos inseridos nas Bibliotecas Digitais UC Digitalis, UC Pombalina e UC Impactum, pressupõem a aceitação plena e sem reservas dos Termos e Condições de Uso destas Bibliotecas Digitais, disponíveis em https://digitalis.uc.pt/pt-pt/termos.

Conforme exposto nos referidos Termos e Condições de Uso, o descarregamento de títulos de acesso restrito requer uma licença válida de autorização devendo o utilizador aceder ao(s) documento(s) a partir de um endereço de IP da instituição detentora da supramencionada licença.

Ao utilizador é apenas permitido o descarregamento para uso pessoal, pelo que o emprego do(s) título(s) descarregado(s) para outro fim, designadamente comercial, carece de autorização do respetivo autor ou editor da obra.

Na medida em que todas as obras da UC Digitalis se encontram protegidas pelo Código do Direito de Autor e Direitos Conexos e demais legislação aplicável, toda a cópia, parcial ou total, deste documento, nos casos em que é legalmente admitida, deverá conter ou fazer-se acompanhar por este aviso.

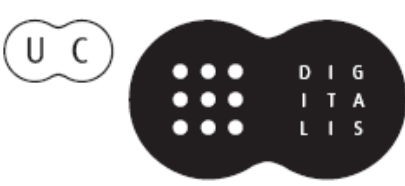




\section{Desplazamientos de la tradición clásica en las culturas hispánicas}

Paola Bellomi, Claudio Castro Filho, Elisa Sartor (eds.)

IMPRENSA DA UNIVERSIDADE DE COIMBRA 


\title{
El mito de la Diosa-Tierra y el Paraíso Perdido en Menesteos, marinero de abril de María Teresa León (The myth of the Goddess-Earth and the Lost Paradise in Menesteos, marinero de abril, by María Teresa León)
}

\author{
María Lourdes Núñez Molina \\ Investigadora independiente (Orcid: 0000-0002-4472-6685)
}

\begin{abstract}
Resumen: Inspirada en los poemas de Ora maritima que Rafael Alberti dedicó a su Cádiz natal, María Teresa León fabula sobre el doloroso destino de Menesteos, fundador mítico de El Puerto de Santa María. Marinero enamorado de un sueño inalcanzable, Menesteos - otrora conductor de carros veloces- deambula por tierras de Tartessos, persiguiendo el recuerdo de una muchacha a orillas del mar. Al construir el relato como un viaje real e imaginario, en el que el héroe ateniense va perdiendo su identidad, la autora proyecta su experiencia como exiliada: la soledad, el paso del tiempo, el anhelo por regresar a la patria, el miedo al olvido... Sin embargo, prevalece una visión esperanzada. María Teresa se reencuentra con la España perdida y añorada, con la plenitud del amor, recreando el mito de la diosa-tierra. Estudiaremos cómo aquella muchacha, de quien Menesteos únicamente conserva la cinta que ataba sus cabellos, aparece transfigurada en elementos de la naturaleza que simbolizan el amor —cuyas connotaciones eróticas enlazan con la tradición del Cantar de los Cantares-y, finalmente, se alza como diosa, "espuma de Venus".

Palabras clave: Menesteos, exilio, mito.
\end{abstract}

Авsтract: Inspired by the poems of Ora maritima, that Rafael Alberti dedicated to his hometown Cádiz, María Teresa León fables about the painful fate of Menesteos, legendary founder of El Puerto de Santa María. A sailor in love with an unattainable dream, Menesteos (a former driver of fast cars) wanders through the land of Tartessos, pursuing the memory of a young girl by the seaside. By constructing the tale as a real and imaginary journey, in which the Athenian hero gradually loses his identity, the author projects her experience in exile: loneliness, the passage of time, the yearning for a return to the motherland, the fear of oblivion... However, a hopeful outlook prevails. María Teresa is reunited with her lost and longed Spain, with the plenitude of love, re-creating the myth of the Earth goddess. We will study how that girl, from whom Menesteos only retains a hair band, appears transfigured in elements of nature that symbolise love - whose erotic connotations are linked to the traditions of the Song of Songs - , finally standing as goddess, "Foam of Venus".

KEYwords: Menesteos, exile, myth.

Dejaba caer mi pelo por la espalda y... ¡Qué bien se hundían mis pies en la arena al correr junto a la línea de la espuma! Se apresuraban los cangrejos. Reuníamos conchillas. Eran nuestra fortuna. Se podían cambiar por besos. Cádiz al frente y toda la playa, todo el mar para nosotros. (León 1999: 194-195) 
Al evocar aquellos días transcurridos en Rota a comienzos de 1931, la plenitud amorosa se funde con la imagen del mar y se torna en metáfora del paraíso perdido. La nostalgia de ese paraíso aviva la composición de uno de sus libros más hermosos, Menesteos, marinero de abril (1965), una novela en la que María Teresa León proyecta su experiencia como exiliada: la soledad, el paso del tiempo, el anhelo por regresar a la patria, el miedo al olvido... Trasfiere esa traumática vivencia a Menesteos — jefe ateniense en la guerra de Troya — quien, cansado de luchar, navega y comercia, hasta que un día desembarca en la costa de Tartessos, enclave mítico donde consuma un azaroso periplo iniciático.

Tras residir veintitrés años en Argentina, el 28 de mayo de 1963 María Teresa inicia una nueva etapa del exilio en Roma ${ }^{1}$. Hasta entonces el destierro había motivado creaciones como Morirás lejos... (1942), Las peregrinaciones de Teresa (1950), Doña Jimena Díaz de Vivar, gran señora de todos los deberes (1960) o Fábulas del tiempo amargo (1962). En la última fábula de esta colección, "Por aquí, por allá", la narradora cumple el deseo de volver a su patria, recorriéndola a lomos de un caballo blanco, un viaje onírico que la conduce a recordar su infancia, su barrio madrileño, los años de la guerra; pero también a sentirse extraña entre su gente, como sucede en la leyenda del santo que quiso gozar del Paraíso - mencionada en la fábula-. Oyendo el deleitoso canto de un pajarillo, el santo se quedó dormido varios siglos. Cuando la avecilla se marcha y despierta de tan largo sueño, nadie lo reconoce, aunque para él solo haya transcurrido un instante ${ }^{2}$. A pesar de que el reencuentro con su pueblo ha sido doloroso, el sueño de la narradora concluye con el deseo de que la dicha alcance a todos los españoles:

¡Qué ancha y grande la tierra fresca de la patria! ¿Estoy despierta? ¡Qué dulzura da ver su extensión! Un claro espejo, unas colinas, una línea blanda, un prodigio de tiempos anteriores nos lleva de la mano. $\mathrm{Y}$ así, pequeños,

${ }^{1}$ El exilio había comenzado el 6 de marzo de 1939. María Teresa y Rafael Alberti vuelan desde Alicante hasta Orán; de ahí, se dirigen a Marsella. A continuación, se instalan en París, donde permanecen casi un año trabajando en Radio París-Mondial. En febrero de 1940 embarcan en el Mendoza rumbo a Argentina. El matrimonio tendría que esperar al 27 de abril de 1977 para regresar a España (Álvarez de Armas 2005: 21, 23 y 24).

${ }^{2}$ Se conocen diversas versiones del cuento del monje y el pajarillo. Por ejemplo, es el motivo de la Cantiga 103 de Alfonso X el Sabio y de "La leyenda del monje Félix", recogida en el Libro de los exenplos por a.b.c. de Clemente Sánchez de Vercial. Cf. Filgueira 1982, quien, además, reproduce dos poemas de Ramón del Valle-Inclán: "Ave Serafín” y "Estela del Prodigio" (Aromas de Leyenda. Versos en loor de un santo ermitaño, 1907), en los que la avecilla que embelesa al santo es un ruiseñor. También María Teresa escoge el melódico canto del ruiseñor como augurio de felicidad, siguiendo una de las tendencias literarias de la Edad Media, en la que el ruiseñor es símbolo de la primavera y del amor (tradición que proviene de Aristóteles, Plinio y Homero, entre otros). La otra tendencia deriva del mito de Filomena, tal como lo relataron Virgilio, en las Geórgicas, y Ovidio, en las Metamorfosis. En esta tradición el ruiseñor personifica el dolor y la tristeza. Cf. Pampín 2001: 63-71. 
dormidos en su pliegue de tierra, alcanzamos el mar [...]. ¡Patria! ¡Patria! ¡Patria! [...]. El ruiseñor cantará para todos. (León 2003: 343)

Esa visión esperanzada se transmite de nuevo en Menesteos, marinero de abril. En las primeras páginas, el lector asiste al encuentro amoroso, a orillas del mar, entre Menesteos - otrora conductor de carros veloces- y una joven virgen, una bailarina de quien el protagonista solo conserva la cinta verde que ataba sus cabellos. Marinero, enamorado de un sueño inalcanzable, vaga por esa tierra ajena, persiguiendo el recuerdo de aquella muchacha, cuya incansable búsqueda es el hilo conductor del relato.

A lo largo del viaje, confunde sueño y realidad, transita espacios reales (plazas, mercados, playas, montañas) e imaginarios (el Infierno y el Paraíso). Algunas de las personas con las que dialoga son meras ilusiones, como el joven dios del ceñidor bermejo que lo dirige hacia las profundidades del Hades, donde se propicia su redención y un simbólico retorno a los orígenes. Con el paso de los años, Menesteos renuncia a regresar a la Hélade y crea un vínculo con aquella tierra, su nueva patria. Goza de la unión con la naturaleza (en la que se refleja y metamorfosea la muchacha) y, al llegar la primavera, es partícipe de su renacimiento. Al final de sus días, el marinero de abril erige un templo destinado a la celebración del amor.

Trataré de esclarecer cómo María Teresa León recrea el mito de la diosa tierra y se reencuentra con la España perdida y añorada, analizando las imágenes que identifican a la muchacha tanto con la tierra como con el mar. El relato aúna la herencia clásica y la bíblica, pues la autora emplea símbolos cuyas connotaciones eróticas enlazan con la tradición del Cantar de los cantares, en sus palabras, el "más sublime canto de amor que conocieron los hombres" (León 2015: 159); y, en las últimas líneas, la niña de la arena se alza como diosa, que habita en el litoral del sur español — “espuma de Venus" (León 1965: 123)—, espacio propicio para el placer.

Antes es oportuno hacer algunas observaciones sobre la gestación del texto. La colaboración artística entre María Teresa León y Rafael Alberti fue frecuente. A modo de ilustración señalaré alguno de sus quehaceres. En mayo de 1933 fundaron la revista Octubre. Escritores y artistas revolucionarios. En diciembre de 1937 llevaron a escena una versión de la Numancia de Cervantes, escrita por el poeta y dirigida por María Teresa, quien también dirigió Cantata de los héroes y la fraternidad de los pueblos de Alberti, como despedida a los brigadistas internacionales en noviembre de 1938. León interpretó el papel de España en ambas (Torres 1996: 41-44). En Argentina firmaron dos guiones cinematográficos (Emiliozzi 2003). El primero es una versión libre de una comedia de Pedro Calderón de la Barca, La dama duende. El film se estrenó en 1945, bajo la dirección de Luis Saslavsky. El gran amor de Bécquer es el segundo. Fue escrito fundamentalmente por María Teresa y daría lugar a la biografía novelada El gran amor de Gustavo Adolfo Bécquer (una vida pobre y apasionada) 
publicada en 1946, mismo año en que se estrenó la película, dirigida por Alberto de Zavalía. Por otra parte, desde finales de los años cincuenta el matrimonio realizó una apreciable labor de traducción: poesía china, canciones populares rumanas, poemas de Mihail Eminescu, Paul Éluard, Tudor Arghezi ${ }^{3} .$.

No ha de extrañar, por tanto, que María Teresa se inspirase en la obra de su esposo, Ora marítima (1953), cuando eligió como protagonista de su tercera novela al fundador mítico de E1 Puerto de Santa María y, posiblemente, a la hora de concebir la atmósfera narrativa (el comercio de minerales, la pesca de atunes, las minas de cobre, las marismas, los toros, las alusiones a Heracles y Geryón) ${ }^{4}$. La dedicatoria - "A Rafael Alberti, de Puerto de Menesteos"-, la transcripción de las citas de Avieno, Homero y Estrabón ${ }^{5}$ y del poema "Menesteos, fundador y adivino", funcionan como proemio a la novela y trazan un vínculo insoslayable con Ora maritima — anotado sobradamente por la crítica— ${ }^{6}$. No obstante, Menesteos, marinero de abril es una creación personal. Las referencias mitológicas (héroes de la guerra de Troya, dioses, amazonas, sirenas, náyades, tritones, centauros, la Gorgona...) proceden de la lectura de "fuentes clásicas", tal y como María Teresa le explica a Max Aub, en carta fechada el 18 de abril de 1964, en la que también ruega su mediación con la Editorial Era para publicar el libro y orienta la lectura de su amigo, indicándole "que sigue la línea de la Doña Jimena" escrita años antes ${ }^{7}$.

Ciertamente, Menesteos y Doña Jimena son dos figuras que se prestan a la meditación sobre el destierro. Al tejer las historias del capitán de la Ilíada y de la

${ }^{3}$ Cf. la bibliografía de Estébanez 2003: 449-450.

${ }^{4}$ Ambientes que aparecen en los poemas "Cádiz, sueño de mi infancia", "Ríotinto, lago del infierno", "Bahía del ritmo y de la gracia", "Canción de los pescadores pobres de Cádiz" y "Menesteos, fundador y adivino" (Alberti 1999: 273-276, 284-286, 293-303). Además, Heracles es "el personaje mítico con más incidencia en Ora marítima, puesto que tres de sus proezas se relacionan con el orbe hispánico, [...] la décima de sus gestas, en la que logró la captura de los toros de Geryón, uno de los tres vástagos de Crisaor, rey de Iberia. La oncena y doceava iban a ser, respectivamente, el robo, en el Jardín de las Hespérides, de las áureas manzanas, y el viaje a los infiernos" (Balcells 2005: 29).

${ }^{5}$ Alberti compuso este poemario con motivo de la conmemoración del tercer milenario de la fundación de su Cádiz natal. María Teresa copia los epígrafes con los que el poeta (1999: 274, 301 y 303) encabezó "Cádiz, sueño de mi infancia": Avieno, Ora marítima 85-86, 261-265, 390-393; y “Menesteos, fundador y adivino”: Homero, Il. II, 546-556 y Estrabón, Geog. III, 2:13; 1: 8 y 9.

${ }^{6}$ Martínez 2013: 83: "Probablemente el mayor estímulo que recibió para crear esta novela fue gracias a un poema escrito una década antes por Alberti". Estébanez 2003: 403: "E1 personaje principal es la figura mítica de Menesteos [...], cantado por Rafael Alberti en su Ora maritima". Ramos 2001: 117: "María Teresa, pues, voluntariamente se convierte en la estela del cometa, Menesteos, marinero de abril sigue la senda de la Ora maritima [...]. Menesteo, pues, se lo debe María Teresa a su compañero sentimental, a su mundo mítico de los orígenes". Torres 1996: 121: "La novelada historia del mítico fundador de E1 Puerto de Santa María no es sino el desarrollo prosístico - y de excelente factura - de un libro, y especialmente de un poema, que en la bibliografía albertiana se llamó Ora marítima".

${ }^{7}$ Carta de María Teresa León a Max Aub, Roma, 18 de abril de 1964. Fundación Max Aub, C-10/30a, C-10/30b, C-10/30c, C-10/30d. 
esposa del Cid, María Teresa incide en que ambos se sienten extranjeros (uno en Tartessos, otra en Valencia); indaga en la terrible soledad, en la angustia causada por el infortunio de vivir en tales circunstancias, como le sucede a ella misma y a tantos desterrados. Dar voz a estos personajes relegados es, en cierto modo, dársela a todos aquellos republicanos, hombres y mujeres anónimos — asesinados, encarcelados o exiliados-, sumergidos en el olvido, "desprendidos del fluir de la historia” (Zambrano 2014:10). Rescatar, recordar, contar sus pequeñas hazañas sería una manera de reintegrarlos en la Historia y de dignificar su memoria ${ }^{8}$.

Retomando la vinculación entre novela y poemario, coincido con Carla Perugini en que existe una divergencia crucial en el tratamiento del personaje. Alberti exalta "la imagen de un héroe divino, numen tutelar de la bahía" (Perugini 2012: 87), ansía que Menesteos, "dios humano" (Alberti 1999: 301), regrese y restaure la libertad en España. En cambio, León suprime parte de los rasgos distintivos del héroe - "el culto público", "la muerte gloriosa" o "su naturaleza semidivina" (Perugini 2012: 87)—y reelabora el relato. Carlos García Gual (1998: 36) estableció cinco modalidades en la "recreación o utilización sesgada de los mitos" cultivada por la literatura moderna, atendiendo a la "presentación" del mito y a "la intención" del autor. Si adoptamos esta clasificación, el desarrollo psicológico y la progresiva humanización de Menesteos constituyen una "amplificatio del esquema mítico"; además, el enfoque crítico de la autora guarda relación con "la reinterpretación subversiva del sentido del mito". María Teresa hace hincapié en la crueldad e inmoralidad inherentes a los conflictos bélicos. Al recordar a los héroes aqueos, sus compañeros de batalla, Menesteos refiere su cansancio, el horror de la guerra — perros y buitres devorando cadáveres-, e insinúa que el rapto de Helena fue un pretexto para entablar una contienda promovida por la ambición. Los dioses no se manifestaron en el momento de la victoria, ni se conmueven ante el sufrimiento, el hambre, la miseria del ser humano; por ello, el marinero ateniense cuestiona su existencia y decide vivir sus últimos días como un hombre humilde, como un anciano sin nombre, dejando atrás sus proezas.

Las fuentes clásicas contienen escasas noticias sobre Menesteos ${ }^{9}$, de manera que María Teresa puede inventar detalles de su historia - por ejemplo, cuando el personaje evoca su infancia en Atenas y su amistad con Arcesilao, jefe de

${ }^{8}$ En Memoria de la melancolía, María Teresa León 1999: 404 pone de relieve la necesidad de dar a conocer la intrahistoria del exilio: "Sí, desterrados de España, contad, contad lo que nunca dijeron los periódicos, decid vuestras angustias y lo horrorosa que fue la suerte que os echaron encima. Que recuerden los que olvidaron".

${ }^{9}$ Menesteos, hijo de Péteo, biznieto del rey Erecteo, fue uno de los pretendientes de Helena. Estuvo al mando de cincuenta naves, durante el ataque a Troya, y permaneció escondido en el caballo de madera. Se le atribuye la fundación del Puerto de Menesteo, cerca de Gades, así como el gobierno de Atenas y el reinado de Melos, después de la caída de Troya. Cf. Homero, Il. II, 546-556; IV, 327-364; XII, 331-363, 373; XIII, 195-196, 689-690, XV, 329-331. Estrabón, Geog. III, 1, 9. Apolodoro, Bibl. III, 10, 8; Epit. 1, 23, 24; 3, 11; 6, 15b. Higino, Fáb. 81,1; 97, 11. 
los beocios en Troya-. Así, en la primera parte de la novela - estructurada en trece capítulos-, la narradora reconstruye su pasado heroico. Resalta su valor, su habilidad para conducir carros "de ruedas inigualables" (León 1965: 19), su afán de gloria e inmortalidad: “-Los aedas ${ }^{10}$ prometieron hablar de mí" (León 1965: 24). Cuenta cómo, movido por el empeño de capturar a Eneas, "se convirtió en capitán de nave” (León 1965: 35), cómo Menesteos se enorgullece de ser "un guerrero de Atenas" (León 1965: 44) y de sus orígenes: “¿No ves que soy un héroe de alta talla? Los hombres me han elegido como jefe de sus carros de guerra [...]. Soy Menesteos, nieto de rey" (León 1965: 53). Aunque vende pescado, "voceando, para poder seguir viviendo" (León 1965: 55), continúa rememorando sus hazañas en Troya: "Él pertenecía a la tercera raza, a la de los héroes”, le dice a un anciano (León 1965: 86).

Sin embargo, la soledad, la desesperación y el paso del tiempo van mudando su naturaleza. En la segunda parte de la novela, un Menesteos desalentado emprende rumbo a las montañas, con la esperanza de reunirse con la muchacha de la playa. Como en el mito de Orfeo y Eurídice, el enamorado descenderá a los infiernos en busca de su amada. Pero, antes de que acontezca la catábasis, la autora reinterpreta el mito de la primavera ligado a Deméter, "diosa de los frutos de la tierra" (Baring y Cashford 2005: 418) y a su hija Perséfone; además de hallarse en la imagen de Afrodita, "emergiendo de las olas", y en la de Gea, "diosa de la tierra, elevándose del subsuelo" (Baring y Cashford 2005: 144-145).

Baring y Cashford (2005: 420-421) consideran que Deméter y Perséfone están tan unidas que forman "una figura con dos apariencias" y se preguntan: “Es esta figura, entonces, la de la gran y única diosa madre en su forma dual, como madre y doncella? ¿Se trata de la faceta más joven y la menos joven de una única figura, madre de los vivos y de los muertos?”. Según el mito, cuando Perséfone es raptada por Hades, Deméter adopta el aspecto de una anciana y, durante un tiempo, permanece en la tierra, siendo nodriza de Demofonte. Tiempo en el que la tierra se vuelve estéril. Para restaurar su fertilidad, Zeus ordena a Hades que libere a Perséfone. Pero, como la joven diosa ha comido un grano de granada, deberá permanecer parte del año en el mundo de los muertos y parte en la tierra, junto a Deméter, iniciándose entonces el ciclo de la primavera. Esta faceta materna de la Tierra, origen de las estaciones, podría tener un correlato en la novela que nos ocupa.

Tras varios días recorriendo las montañas, Menesteos encuentra una cabaña habitada por una mujer de "cara marchita" y "pechos hermosos" (León 1965: 61), es decir, que posee doble apariencia. El olor de "la leche batida" (León 1965: 62) le hace evocar su infancia: "- Hay horas en que los hombres únicamente

${ }^{10}$ Según Bauzá 1998: 31, "la poesía, a través de la taumaturgia de su canto, confiere de alguna manera una suerte de inmortalidad”. 
desearíamos dormir sobre unos senos cansados de alimentarnos" (León 1965: 63), le confiesa a la mujer. Esta le ofrece leche y "un caramillo" (León 1965: 64) para que cante sus penas de amor; poco después, se desvanece y "Menesteos, niño de Atenas, cerró los ojos para encontrar su cuna” (León 1965: 65). Cuando despierta, a su lado, cobijándose de la lluvia, descansan unos arrieros. El héroe les propone intercambiar queso por vino, pero mujer, leche, quesos y cabritillos han desaparecido, por lo que creen que es un loco embustero. La lluvia cesa. $\mathrm{Al}$ amanecer, Menesteos halla el caramillo, única certeza "de no haber soñado despierto" y sopla: "Un sonido ligero se fue desplegando por el monte. [...] y ante los ojos de los mal despiertos la primavera ganó las vertientes, cubriéndolas de hojitas menudas, de miradas azules, de lirios blancos. Nada quedó desnudo" (León 1965: 70). Otros hombres van llegando y contemplan asombrados aquel "prodigio", al marinero, cual Orfeo, ayudando "a las aves a volar", "al sol a crecer" y a florecer a "las plantas que adornan el vestido de Deméter, a la que ellos llamaban únicamente la Tierra” (León 1965: 71).

Menesteos reanuda el viaje. Rodeado de las incipientes plantas, oye un silbido que detiene sus pasos y, creyendo seguir el rastro de la cinta de la muchacha, es picado por una serpiente - recordemos que Eurídice muere por la picadura de una serpiente- Un grupo de íberos lo salvan de la muerte y lo trasladan a su aldea. Allí asiste al sacrificio de una doncella. Acabado el banquete, se encamina hacia las cumbres, donde trabajan los mineros y, al fin, penetra en el Hades. Pero, una vez llega al "hogar de los difuntos" (León 1965: 89), se siente engañado, pues "[e]stá en el cero del tiempo" (León 1965: 90), completamente solo: “¿Dónde están los dioses o las madres terribles de la tierra, Gea la devoradora o Perséfone...?” (León 1965: 91), le reprocha al joven que le guía. Entonces proclama ser "solamente un hombre" (León 1965: 92) y rehúsa la sabiduría que pueda revelársele, porque eso significaría olvidar: “¿Qué voy a hacer ahora si la olvido en esta cueva o cáscara final donde todo se desvanece?” (León 1965: 92-93).

Siguiendo el estudio de José Antonio Molina Gómez (2006: 862), la cueva "en la mentalidad primitiva aparece como símbolo del útero de la Madre Tierra, [...] que se pone en relación con la renovación natural de los seres vivos que emergen de la matriz cósmica". Al adentrarse en el Infierno, Menesteos cumple un rito de iniciación ${ }^{11}$, una muerte simbólica que le libera, permitiéndole disfrutar de un instante en el Paraíso - asunto que estudiaremos más adelante- A su "regreso de la cueva del sueño" (León 1965: 95) y culminado el deleite, duda de su identidad: "¿Soy verdaderamente sólo una brizna soplada por la desventura? Yo el mendigo, que monta un caballo ajeno ¿fui de verdad descendiente de reyes?

${ }^{11}$ Wolfzettel 2005: 18-19 explica que el rito iniciático "exige [...] que el viajero pase por el infierno antes de poder alcanzar el paraíso, porque no es posible omitir escalones (gradus) del itinerario iniciático. [...] la redención no es posible sin la muerte simbólica”. 
¿Yo, ilustre entre los atenienses? ¿¿Descendiente de Erecteo? ¿Paladín en Troya?...” (León 1965: 104). Este monólogo interior refleja que un destierro dilatado trae consigo la idea de pérdida de la identidad. El desterrado siente que está condenado a ser alguien sin identidad, a ser un "forastero", un "extranjero", un "extraño", un "mendigo"12 a quien pueden marginar y expulsar en cualquier momento. De ahí que, poco antes de morir, el héroe acepte su destino y se niegue a pronunciar su nombre: “-Ese es mi nombre. Mendigo soy y por mendigo respondo" (León 1965: 114), alejándose de los hombres que lo han interrogado, para cavar su tumba y hallar la anhelada paz.

Espacio y tiempo perdidos son dos de las preocupaciones del exiliado, además de la ya citada quiebra de la identidad. Andrea Luquin Calvo (2012: 376) explica cómo la nostalgia y "el propio sentido del espacio como soporte de nuestras acciones" son abordados con frecuencia por los escritores desterrados, quienes se valen de la memoria para afrontar el desarraigo y procurar que su identidad no se diluya. Si la muchacha de la playa es metáfora de España, su ausencia lo es del exilio, por lo que su encuentro es concebido por la autora como “la absolución de los trabajos" (León 1965: 95). En el recuerdo, la patria amada y perdida es idealizada por María Teresa, que la imagina como una madre, fuente de vida a la que desea regresar. Imagina que Menesteos era uno de aquellos navegantes ávidos de aventuras que olvidan "la tierra en que bebieron leche materna y nombre" (León 1965: 33). Pero su prolongada estancia en Tartessos, "tierra de piel dura" (León 1965: 81), a la que llega a amar, constituye un retorno a los orígenes. El personaje renace y muere en conexión con la naturaleza, lo que sugiere una conciencia de unidad cósmica, afín al culto a la divinidad femenina y a la mística (Molpeceres 2012). Uno de los motivos principales de la literatura mística es "el amor nupcial a lo divino", es decir, el anhelo de unión con Dios, que toma como modelo el Cantar de los cantares (Hernández 2011: 21), cuya impronta se aprecia en Menesteos, marinero de abril, en el deseo que mueve al protagonista a proseguir su búsqueda.

Flores, frutos, animales y una serie de símbolos eróticos e imágenes sensuales dirigen nuestra atención hacia la tradición del Cantar de los cantares. E1 poema bíblico llega a María Teresa a través de la traducción del hebreo de Fray

${ }^{12}$ María Teresa compara, a menudo, la situación del desterrado con la del menesteroso. Ejemplo de ello es el cuento "Morirás lejos", protagonizado por un coleccionista innominado que, a causa de la guerra y del éxodo, parece "de los más miserables. [...] un pordiosero aseñorado" (León 2003: 226). Para sortear los derechos de aduana y poder desembarcar en América, este hombre debe renunciar a sus preciadas monedas —única pertenencia-. El relato se cierra con amarga ironía. La guerra le ha arrebatado todo, salvo la libertad de afeitarse los bigotes, "para que se quedasen también” (León 2003: 227) con ellos. En su libro de memorias, la autora se vale nuevamente de este símil: "aunque parezcamos mendigos, los españoles debemos seguir pidiendo, contando, hablando, iluminando las cárceles oscuras para que la gente mire, vea y compare" (León 1999: 474). 
Luis de León - su lectura a tres voces fue una de las Charlas de María Teresa que emitió, en 1943, Radio E1 Mundo de Buenos Aires- (León 2015: 159-167). En el Prólogo, Fray Luis (2002: 22-23) interpreta el texto bíblico como "una égloga pastoril" y señala algunos tópicos de la poesía amorosa, como el de morir de amor, empleado también por María Teresa. Llama la atención que el peregrinaje de Menesteos siga el modelo tradicional de la buida. Ante la ausencia de la amada, el amado sale en su busca y pregunta a todos aquellos que se cruzan en su camino si la han visto: “¿No habéis visto por estos montes a una criatura que me huyó desde la misma orilla del mar?” (León 1965: 71). Como en el Cantar, la Esposa anhela encontrar al Esposo y pregunta: "¿Vísteis, por ventura, al que ama mi alma?" (Ct 3, 3). Citaré solo algunos versículos que contienen motivos que pueden rastrearse en la novela:

Béseme de besos de su boca; que buenos [son] tus amores más que el vino $(\mathrm{Ct}$ $1,1)$.

Llévame en pos de ti, correremos (Ct 1,3).

A la yegua mía en el carro de Faraón te comparo, amiga mía (Ct 1,8).

Semejante es mi Amado a la cabra montés, o ciervecito (Ct 2, 9).

Huerto cercado, hermana mía, Esposa; huerto cercado, fuente sellada (Ct 4, 12).

¿Quién te me dará, como hermano, que mamases los pechos de mi madre? Hallarte ía fuera; besárate y ya nadie me despreciaría $(\mathrm{Ct} 8,1)$.

Besos, vino, higuera, granados, lirios, rosas, palomas, cabras, tórtolas, el amado como ciervo, la amada como yegua, pero, sin duda, lo más significativo es que, tras su paso por el Infierno, tiene lugar el soñado encuentro entre Menesteos y la niña de la playa, que brota de su interior. Juntos recorren un naranjal, que no es sino la evocación del hortus conclusus del Cantar, donde los amantes alcanzan el éxtasis amoroso amoroso - "sus bodas reales con la naturaleza ilimitada" (León 1965: 96) —. El marinero y el vergel se funden: "sentía que [...] sus pies desnudos se combinaban estrechamente con la tierra" (León 1965: 97). Según ha anotado Pociña (2004: 271), en el tópico del locus amoenus se distinguen dos fuentes, "la Biblia y la lírica bucólica pagana clásica”, a las que se suma

la notable influencia del Cantar de los cantares, que contiene un nuevo aspecto del paraje ameno: la metáfora del jardín como "cuerpo femenino", con toda una serie de relaciones simbólicas entre las partes físicas de la mujer y los elementos florales o animales presentes en el lugar ameno.

En el vergel-naranjal de la novela confluyen la tradición bíblica y la clásica, puesto que la niña se identifica con el huerto, pero también con Afrodita, mediante el deseo y la "fertilidad" (Baring y Cashford 2005: 401-407) que la diosa 
despierta a su paso tras surgir del mar ${ }^{13}$. Menesteos, pleno de felicidad, exclama: “DDulce bien! como si levantase entre sus manos un coral blanco de muchos brazos, cruzado por sorprendentes pececillos verdes" (León 1965: 96), y luego leemos: "Todas las especies puras de la tierra levantaron al arrullo del hombre su vuelo nupcial, [...] los animales [...] sensibles a los cambios de tiempo, galopaban hacia el placer de la fecundación" (León 1965: 96-97). Menesteos "recorría las Hespérides sin encontrar dragones fulgurantes" (León 1965: 97) ni manzanas de oro. En su lugar, se habla de naranjas. María Teresa introduce este cambio con el fin de recrear un entorno menos fabuloso y un tiempo alejado de la Edad Dorada. Si bien podría tratarse del influjo de un referente literario destacado en la prosa de la autora: la lírica tradicional, donde tanto la manzana como la naranja $^{14}$ son frutos eróticos e imagen simbólica de la mujer amada (Devoto 1974: 423). O sencillamente ser un guiño afectivo. Mientras se alejaba de España, recuerda que vio "los últimos naranjos de los huertos" (León 1999: 431).

Resta añadir que el Cantar de los cantares adopta la forma de diálogo amoroso y este halla su reflejo en la novela. Primero es el héroe quien dirige palabras tiernas a la muchacha, transfigurada en liebre, buscando aliviar su propia aflicción. Y, más tarde, cuando el vergel se ha desvanecido y la desesperación vuelve a invadir a Menesteos, surge el yo femenino, que susurra a través del barro, tratando de consolar al marinero:

humedéceme los labios con vino para entrar dulcemente en el reposo [...]. Ya no corren carrera la amada y el amante. Junta a los míos tus pies. Trénzalos. Reposa. Apoya tus labios en mi hombro. Duerme. Nos cubre el alba. Sí, no hay menoscabo en decirte dueño, amigo, vida, destino, amor... (León 1965: 109)

Si bien no logra serenar su ánimo. Vencido por el paso del tiempo, por el desdén con que es tratado, considera que ha llegado el momento de morir. En el último capítulo, se revela un sentido sagrado del locus amoenus (Pociña 2004:

${ }^{13}$ De los genitales de Urano, cortados y arrojados al mar por Crono, nace Afrodita, según relata Hesíodo, en Teogonía (vv. 188-195): "Los genitales, [...] fueron llevados a través del mar durante mucho tiempo; a ambos lados, blanca espuma surgía del inmortal miembro y, en medio de aquélla, una muchacha se formó [...]. Salió del mar la respetable bella diosa y bajo sus delicados pies a ambos lados la hierba crecía".

${ }_{14}$ Según Calderón 1996: 154, "la manzana, prescindiendo de que el sintagma 'manzanas de oro' pueda significar 'naranjas', tiene precedentes clásicos, bíblicos y folklóricos”. En la tradición lírica española, manzanas, naranjas y limones, "arrojados por los amantes, sugieren el intercambio amoroso y el juego erótico” (Trubarac 2001: 323). Margit Frenk 2003: 1150-1154 recoge dos variantes ilustrativas de esta interpretación: "Arrojóme las naranjillas / con los ramos del blanco açar, / arrojómelas y arrojéselas / y bolviómelas a arrojar" (núm. 1622 A) y "Arrojóme las mançanillas / por encima del verde olivar, / arrojómelas y arrogéselas / y volviómelas a arrojar” (núm. 1622 C). 
274). Un día, Menesteos se detiene en un paraje apacible "donde únicamente vivían los ánades de dos en dos. Algunas tortugas medían la orilla, cautas y perezosas, y la paz mecía los juncos al desplazarse el viento. Buen lugar para una cita de amor" (León 1965: 118). Se propone cavar su tumba, pero el tacto de la tierra le hace rememorar el hogar: "Por primera vez sus manos levantaron la corteza de la madre común. Ahondó con un palo, con las uñas las entrañas de Deméter. [...] y se dijo: ¿Qué semilla dejaré caer en los surcos? pues confundido se creía labrador de su casa" (León 1965: 119).

Más tarde, otros hombres van llegando y le ayudan en su labor que, en realidad, consiste en erigir un santuario para festejar el "amor humano". La niña, que se había ido transfigurando en animales (cierva, garza, liebre...), ahora se le aparece como una diosa: "¿Has llegado andando? Déjame tenderte a secar pues aún traes espuma de la leche de tu madre [...]. Ríete, para que ondules como el oleaje [...]. Amor, niña, sonrisa, nacimiento, burbuja de la vida [...] ¿Por qué huiste de mí, marinero de tu barca, patrón de tu boca?" (León 1965: 121-122). La diosa besa al marinero y desaparece. Entonces "el héroe dejó caer su rostro sobre la tierra, muerto" (León 1965: 122) y fue olvidado hasta que, "una tarde un geógrafo descubrió la piedra fundamental de esta historia: PUERTO DE MENESTEOS” (León 1965: 123). Pero nadie llegó a conocer sus andanzas, ni cuál fue la causa que le alentó a fundar un puerto en la bahía gaditana, hoy conocido como E1 Puerto de Santa María.

Al concebir el azaroso destino de Menesteos, María Teresa León da cauce a su propio dolor. Entabla un apasionado diálogo con la tierra deseada, a la que da apariencia de mujer, emprendiendo una búsqueda interior que le permite reconciliar sueño y realidad, reintegrarse en sus raíces y recuperar el paraíso perdido. $\mathrm{El}$ ahondamiento en la psicología del personaje revela la dualidad que experimenta quien ha perdido su patria: dolor/alegría, vida/muerte, memoria/olvido, lugar/no lugar. Si bien las connotaciones del mar, el naranjal, la primavera y la fundación del templo - espacio propio que suple al que le ha sido arrebatadoinvitan a pensar que, más allá de ser expresión del exilio, Menesteos, marinero de abril es un canto a la vida, al amor, a la esperanza. Por eso, quisiera terminar con las emotivas palabras que María Teresa dirige a Max Aub, meses antes de su publicación, pues dejan entrever la ilusión con que la escritora fragua el texto: "Creo que tus manos tendrán magia y veré navegar al marinero. Puede que sea bonito con ilustraciones. Fotos de piedras, de vasos griegos, de toros ibéricos, de orígenes de la vida... y Afrodita, desnuda... claro es"15.

${ }^{15}$ Carta de María Teresa León a Max Aub, Roma, 21 de agosto de 1964. Fundación Max Aub, C-10/33a, C-10/33b. 


\section{Bibliografía}

Alberti, Rafael (1999), Retornos de lo vivo lejano; Ora marítima (ed. de Gregorio Torres Nebrera). Madrid: Cátedra.

Álvarez de Armas, Olga (coord.) (2005), María Teresa León. Memoria de la hermosura. Madrid: Fundación Autor.

Apolodoro (2004), Biblioteca mitológica (traducción, introducción y notas de Julia García Moreno). Madrid: Alianza.

Balcells, José María (2005), "El viaje mítico en Ora maritima de Rafael Alberti”, Estudios Humanisticos. Filología, núm. 27: 25-42.

Baring, Anne; Cashford, Jules (2005), El mito de la diosa. Evolución de una imagen (pról. de Sir Laurens van der Post, trad. de Andrés Piquer, Susana Pottecher, Francisco del Río, Pablo A. Torijano, Isabel Urzáiz). Madrid: Siruela.

Bauzá, Hugo Francisco (1998), El mito del héroe. Morfología y semántica de la figura heroica. Buenos Aires: FCE.

Calderón, Manuel (1996), La lírica de tipo tradicional de Gil Vicente. Madrid: Universidad de Alcalá de Henares.

Devoto, Daniel (1974), Textos y contextos. Estudios sobre la tradición. Madrid: Gredos.

Emiliozzi, Irma (2003), "Presencia de Rafael Alberti y María Teresa León en el exilio: sus colaboraciones en el cine argentino", Boletín Hispánico Helvético, vol. 2 [www.sagw.ch/dms/sseh/publications/untitled/untitled1/06Emiliozzi, último acceso: 23 oct. 2016].

Estébanez Gil, Juan Carlos (2003), María Teresa León. Escritura, compromiso y memoria (pról. de Julio Valdeón). Burgos: Fundación Instituto Castellano y Leonés de la Lengua.

Estrabón (2015), Geografía de Iberia (traducción de Javier Gómez Espelosín; presentaciones, notas y comentarios de Gonzalo Cruz Andreotti, Marco V. García Quintela y Javier Gómez Espelosín). 2a ed. Madrid: Alianza.

Filgueira Valverde, José (1982), Tiempo y gozo eterno en la narrativa medieval (la Cantiga CIII). Vigo: Edicións Xerais de Galicia.

Frenk Alatorre, Margit (ed.) (2003), Nuevo corpus de la antigua lírica popular bispánica (siglos XV a XVII), 2 vols. México: Facultad de Filosofía y Letras-UNAM. El Colegio de México. FCE, vol. II, 1150-1154.

García Gual, Carlos (1998), "Sobre la reinterpretación literaria de mitos griegos: ironía e inversión del sentido", en Blesa, Túa (ed.), Mitos. Actas del VII Congreso Internacional de la Asociación Española de Semiótica celebrado en la Universidad de Zaragoza del 4 al 9 de noviembre de 
1996, 3 vols. Zaragoza. Asociación Española de Semiótica y Tropelías. Revista de Teoría de la Literatura y Literatura Comparada. Universidad de Zaragoza, vol. I, 34-41.

Hernández Villalba, Afhit (2011), "Misticismo y poesía: elementos retóricos que conforman la estética mística", Revista de El Colegio de San Luis, núm. 2: $10-34$.

Hesíodo (2008), Teogonía. Trabajos y días. Escudo. Certamen (introducción, traducción y notas de Adelaida Martín Sánchez y María Ángeles Martín Sánchez). 5ª reimpresión. Madrid: Alianza.

Higino (2009), Fábulas mitológicas (traducción, introducción y notas de Francisco Miguel del Rincón Sánchez). Madrid: Alianza.

Homero (2006), Ilíada (introducción, traducción y notas de E. Crespo; índice onomástico de M. Cuesta; revisión de C. García Gual). Madrid: Gredos.

León, Fray Luis de (2002), Cantar de los cantares de Salomón (ed. de Javier San José Lera). Salamanca: Ediciones Universidad de Salamanca.

León, María Teresa (2015), Trabajos de una desterrada (ed. de Gabriel Cacho Millet). Madrid: Sial.

(2003), Fábulas del tiempo amargo y otros relatos (ed. de Gregorio Torres Nebrera). Madrid: Cátedra.

(1999), Memoria de la melancolía (ed. de Gregorio Torres Nebrera). Madrid: Clásicos Castalia.

- (1965), Menesteos, marinero de abril. México: Era.

Carta de María Teresa León a Max Aub, Roma, 21 de agosto de 1964. Fundación Max Aub, C-10/33a, C-10/33b.

- Carta de María Teresa León a Max Aub, Roma, 18 de abril de 1964. Fundación Max Aub, C-10/30a, C-10/30b, C-10/30c, C-10/30d.

(1960), Doña Jimena Díaz de Vivar, gran señora de todos los deberes. Buenos Aires: Losada.

(1950), Las peregrinaciones de Teresa. Buenos Aires: Botella al mar.

(1946), El gran amor de Gustavo Adolfo Bécquer (una vida pobre y apasionada) con las Rimas del poeta, un poema y un epílogo de Rafael Alberti. Buenos Aires: Losada.

(1942), Morirás lejos... Buenos Aires: Americalee.

Luquin Calvo, Andrea (2012), "El espacio, la palabra, el nombre: identidad y destierro en el exilio español de 1939”, en Caballero Rodríguez, Beatriz; López Fernández, Laura (eds.); Bowron, Tim (ed. asistente), Exilio $e$ identidad en el mundo hispánico: reflexiones y representaciones. Alicante: Biblioteca Virtual Miguel de Cervantes [http://www.cervantesvirtual. com/nd/ark:/59851/bmcnk413, último acceso: 23 oct. 2016]. 
Martínez García, Ana (2013), "Reinventando mitos desde la distancia: María Teresa León y su Menesteos, marinero de abril", Ubi sunt?, núm. 28: 78-88.

Molina Gómez, José Antonio (2006), "La cueva y su interpretación en el cristianismo primitivo", Antigüedad y cristianismo. Monografías históricas sobre la Antigüedad tardía, núm. 23: 861-880.

Molpeceres Arnáiz, Sara (2012), "Aspectos femeninos de la divinidad en la literatura mística de las tres culturas", Tonos digital. Revista Electrónica de Estudios Filológicos, núm. 22: 1-32.

Pampín Barral, Mercedes (2001), “"Cantan ruyseñores cantares más de çiento»: la evolución del canto del ruiseñor en la poesía cancioneril”, en Alvar, Carlos et al. (ed.), Lyra minima oral. Los géneros breves de la literatura tradicional. Actas del Congreso Internacional celebrado en la Universidad de Alcalá el 29 y 30 de octubre de 1998. Alcalá de Henares: Universidad de Alcalá [www.lyraminima.culturaspopulares.org/actas/alcala/07pampin.pdf].

Perugini, Carla (2012), "Menesteos, el antihéroe de María Teresa León”, en Losada Goya, José Manuel; Guirao Ochoa, Marta (eds.), Myth and Subversion in the Contemporany Novel. Cambridge: Cambridge Scholars Publishing, 81-91.

Pociña López, Andrés José (2004), “Tópicos literarios en la lírica de Gil Vicente: el tópico del locus amoenus", en Sánchez Marín, José A.; Muñoz Martín, M. Nieves (eds.), Retórica, Poética y géneros literarios. Granada: Universidad de Granada, 267-287.

Ramos Jurado, Enrique Ángel (2001), Cuatro estudios sobre tradición clásica en la literatura española (Lope, Blasco, Alberti y Maria Teresa León, y la novela bistórica). Cádiz: Servicio de Publicaciones Universidad de Cádiz.

Torres Nebrera, Gregorio (1996), Los espacios de la memoria (La obra literaria de María Teresa León). Madrid: Ediciones de la Torre.

Trubarac, Djordjina (2001), "Las manzanas de oro: un motivo en las líricas populares española y serbia”, Dicenda. Cuadernos de Filología Hispánica, núm. 19: 315-336.

Wolfzettel, Friedrich (2005), "Relato de viaje y estructura mítica", en Romero Tobar, Leonardo; Almarcegui Elduayen, Patricia (coords.), Los libros de viaje: realidad vivida y género literario. Madrid: Universidad Internacional de Andalucía/ Akal, 10-24.

Zambrano, María (2014), El exilio como patria (presentación de Eduardo González Di Pierro; edición, introducción y notas de Juan Fernando Ortega Muñoz). Barcelona: Anthropos; México: Universidad Michoacana de San Nicolás de Hidalgo/ Instituto de Investigaciones Filosóficas «Luis Villoro». 